\title{
Three-dimensional Display Systems in Ophthalmic Surgery - A Review
}

\author{
Nuno Moura-Coelho, 1,2 José Henriques, ${ }^{3,4}$ João Nascimento, ${ }^{4,5}$ Marco Dutra-Medeiros 1,2,4,6 \\ 1. Ophthalmology, Central Lisbon University Hospital Center, Lisbon, Portugal; 2. Faculty of Medical Sciences, NOVA Medical School, University of Lisbon, \\ Lisbon, Portugal; 3. Gama Pinto Ophthalmology Institute, Lisbon, Portugal; 4. Lisbon Retinal Institute, Lisbon, Portugal; 5. Ophthalmology, Hospital Beatriz \\ Ângelo, Lisbon, Portugal; 6. Ophthalmology, Associação Protectora dos Diabéticos de Portugal, Lisbon, Portugal
}

DOI: https://doi.org/10.17925/EOR.2019.13.1.31

\section{Keywords}

Three-dimensional display system, heads-up display system, head-mounted display system, ophthalmic surgery, innovation

Disclosure: Nuno Moura-Coelho, José Henriques, João Nascimento and Marco Dutra-Medeiros have nothing to declare in relation to this article.

Review Process: Double-blind peer review.

Compliance with Ethics: This study involves

a review of the literature and did not involve any studies with human or animal subjects performed by any of the authors.

Access: This article is freely accessible at touchOPHTHALMOLOGY.com.

C Touch Medical Media 2019.

Authorship: The named authors meet the International Committee of Medical Journal Editors (ICMJE) criteria for authorship of this manuscript, take responsibility for the integrity of the work as a whole, and have given final approval for the version to be published.

Received: 11 June 2019

Accepted: 22 July 2019

Citation: European Ophthalmic Review. 2019;13(1):31-6

Corresponding Author: Nuno Moura-Coelho, Alameda Santo António Capuchos, 1169-050 Lisbon,

Portugal. E: nunomouracoelho.oft@gmail.com

LinkedIn Profile: www linkedin.com/in/

nuno-moura-coelho-5ab03a135

Support: No funding was received for

the publication of this article.
Over the past two decades, new innovations have led to a dramatic increase in the number of microsurgeries performed in many surgical specialties. However, microsurgery using the traditional binocular microscope can lead surgeons to deleterious neck and back postures that cause musculoskeletal fatigue and injuries, which has been associated with reduced surgical longevity. ${ }^{1}$ The prevalence of neck, upper-body, or lower-back symptoms among ophthalmologists has been reported to be as high as $62 \%{ }^{2-4}$ vitreoretinal surgeons might be a particularly high-risk group in this regard. ${ }^{5}$

Live three-dimensional (3D) display systems have been introduced in medicine with the creation of the TrueVision ${ }^{\circledR}$ 3D Visualization System (TrueVision Systems Inc., Santa Barbara, CA, USA) for microsurgery. To date, 3D visualisation systems have had application in many surgical specialties, including neurosurgery, ${ }^{6,7}$ otolaryngology, ${ }_{1}^{8,9}$ maxillofacial surgery, ${ }^{10}$ plastic surgery, ${ }_{1}^{1}$ urology, ${ }_{1}^{11}$ general surgery, ${ }^{12,13}$ orthopaedics ${ }^{14}$ and ophthalmology.

3D systems are classified as either passive or active systems. ${ }^{15}$ In passive systems, the 3D image is acquired by mixing two images horizontally and then passively separating them into polarised 3D glasses. This is the principle used in current heads-up display systems. In active systems, the 3D image is obtained by showing high-speed consecutive images for the right and left eyes alternately, while a special pair of electronic glasses actively suppress the image in the other eye. ${ }^{15}$ This is the principle used in most head-mounted systems.

\section{Literature review}

We searched PubMed database, Google Scholar, and Research Gate for published papers regarding 3D visualisation systems in ophthalmic surgery, as well as relevant abstracts of personal communications held at meetings of ophthalmology, up to 14 June 2019. In addition, we manually searched the reference lists of most primary articles.

\section{Heads-up surgery in ophthalmology}

The term 'heads-up surgery' describes the performance of microsurgical procedures not by looking at the eyepieces of the microscope, but by viewing the microscopic image on a panel display sent from a 3D camera. ${ }^{16}$ It is derived from the so-called 'heads-up display', a display system first used in aircraft flight decks, which projects an image into the normal field of view. This heads-up display system allows visualisation in a 'heads-up' position. These terms differ in that the image in heads-up surgery is shown on a display rather than projected. Heads-up surgery eliminates the constraints imposed by the standard binocular microscope and minimises fatigue by providing greater degrees of freedom to operate in a more neutral, physiologic position, without affecting the image quality or technical difficulty. 
Table 1: Clinical experience with 3D heads-up viewing systems in cataract and anterior segment surgery

\begin{tabular}{|c|c|c|c|c|c|}
\hline Authors & Technology & Study & Surgery & Outcomes & Comments \\
\hline $\begin{array}{l}\text { Weinstock et al. } \\
\text { 2010;17 } \\
\text { Weinstock } 2011^{18}\end{array}$ & $\begin{array}{l}\text { TrueVision }^{\circledR} \text { 3D System } \\
\text { (TrueVision Systems Inc., } \\
\text { CA, USA) }\end{array}$ & $\begin{array}{l}\text { Conventional binocular } \\
\text { microscope versus HUS }\end{array}$ & $\begin{array}{l}\text { Cataract } \\
\text { surgery }\end{array}$ & $\begin{array}{l}\text { Excellent outcomes in both } \\
\text { patient groups }\end{array}$ & $\begin{array}{l}\text { The rate of unplanned vitrectomy } \\
\text { was three-times higher in the } \\
\text { standard microscope group } \\
\text { compared with the heads-up group }\end{array}$ \\
\hline $\begin{array}{l}\text { Mohamed et al. } \\
2017^{22}\end{array}$ & $\begin{array}{l}\text { Sony HD Medical } \\
\text { Display System (Sony } \\
\text { Electronics, Tokyo, } \\
\text { Japan) }\end{array}$ & Case report & nDSAEK & $\begin{array}{l}\text { Good anatomic and visual } \\
\text { outcome. Procedure prior to graft } \\
\text { insertion in the AC was easy due } \\
\text { to high magnification }\end{array}$ & $\begin{array}{l}\text { Required frequent focus change } \\
\text { during surgery due to difficulty in } \\
\text { detecting the graft depth in the AC }\end{array}$ \\
\hline $\begin{array}{l}\text { Galvis et al. } \\
2017^{23}\end{array}$ & $\begin{array}{l}\text { Ultra HD (4K) camera, } \\
\text { unspecified device }\end{array}$ & Case report & DMEK & $\begin{array}{l}\text { Good postoperative outcome. } \\
\text { Easy learning curve, enhanced } \\
\text { depth of field, colour contrast, } \\
\text { and size/quality ratio compared to } \\
\text { traditional microscope }\end{array}$ & $\begin{array}{l}\text { Moutsouris' sign was much more } \\
\text { evident in the 3D screen }\end{array}$ \\
\hline $\begin{array}{l}\text { Hamasaki et al. } \\
2019^{26}\end{array}$ & $\begin{array}{l}\text { NGENUITY 3D } \\
\text { Visualization System }\end{array}$ & $\begin{array}{l}\text { Small case series of surgery } \\
\text { conducted without surgical } \\
\text { light or light source of the } \\
\text { microscope }\end{array}$ & $\begin{array}{l}\text { Strabismus } \\
\text { surgery }\end{array}$ & $\begin{array}{l}\text { Strabismus surgery could be } \\
\text { performed without special } \\
\text { illumination, potential to reduce } \\
\text { phototoxic injury }\end{array}$ & $\begin{array}{l}\text { Reduced need to supply saline for } \\
\text { eye dryness during the procedure; } \\
\text { raised concern for assistant's } \\
\text { discomfort and logistics }\end{array}$ \\
\hline
\end{tabular}

3D = three-dimensional; $A C=$ anterior chamber; DMEK = Descemet membrane endothelial keratoplasty; $H D=$ high definition; HUS = heads-up system; nDSAEK = non-Descemet stripping automated endothelial keratoplasty.

\section{Three-dimensional heads-up display system in ophthalmology \\ Cataract and anterior segment surgery}

In ophthalmology, cataract and anterior segment surgery in human eyes using heads-up surgery was first reported by Weinstock et al. ${ }^{17,18}$ They presented a retrospective analysis comparing cataract surgery using a standard binocular microscope with a microscope equipped with TrueVision 3D system. Excellent outcomes were reported in both groups with minimal procedure time difference between groups. In this pilot study, the rate of unplanned vitrectomy was three times higher in the standard microscope group compared with the TrueVision group. ${ }^{17}$ Hypothetically, superior depth perception and higher magnification of the image may be factors associated with reduced risk of posterior capsular rupture and improved anterior vitrectomy, but from our experience we cannot readily confirm this. Besides, the same study group has recently published conflicting findings, supporting the notion that the complication rate is similar between 3D heads-up display and traditional binocular microscope. ${ }^{19}$

The TrueVision 3D Surgical System is a camera unit that attaches to standard surgical microscopes, sending stereoscopic images and video to a 3D, high-definition (HD), large-screen monitor position a few feet from the surgeon, providing visualisation in real time. The US Food and Drug Administration (FDA) has granted clearance for the TrueVision Refractive Cataract Toolset ${ }^{\oplus}$, an application that provides 3D graphical overlays for image-guided cataract surgery. ${ }^{20}$ More recently, TrueVision has developed the TrueGuide ${ }^{\circledast}$ and the TruePlan ${ }^{\circledR}$ applications, which have been designed for intelligent surgical planning to aid in achieving targeted refractive outcomes, including the use of toric intraocular lenses (IOLS). This information is available at the company's official website. ${ }^{21}$ In one study (Solomon J, 2014, personal communication, American-European Congress of Ophthalmic Surgery, Deer Valley, UT, USA), toric IOL implantation using TrueGuide ${ }^{\circledast}$ resulted in $83.3 \%$ of eyes corrected to $<0.50 \mathrm{D}$ of cylinder, and $100 \%$ of eyes corrected to $<1.00 \mathrm{D}$ cylinder. In addition, $80 \%$ of the eyes had final vision $20 / 20$, and $100 \%$ of the eyes achieved $20 / 25$ or better.

Other anterior segment surgeries have also been performed using the heads-up surgery, including amniotic membrane transplantation (Uematsu M, 2017, personal communication, 21st European Society of Cataract and Refractive Surgeons Winter Meeting, Maastricht, The Netherlands), and corneal surgeries, including non-Descemet stripping automated endothelial keratoplasty (nDSAEK) for post-traumatic bullous keratopathy, ${ }_{1}^{22}$ and Descemet membrane endothelial keratoplasty (DMEK), ${ }^{23}$ with reported great visual experience and ergonomics. Interestingly, although visual experience for DMEK was reported as superior using the $3 \mathrm{D}$ heads-up display system, ${ }^{23}$ frequent focus changing to detect the graft in the anterior chamber was reported with nDSAEK.22 In a recent study of 200 consecutive surgeries using the NGENUITY ${ }^{\circledR}$ 3D Visualization System (Alcon, TX, USA), some extraocular muscle and anterior segment surgeries were performed; 24 however, the surgical experience of the authors specifically concerning these cases is not detailed. ${ }^{24}$ In another study, pars plana vitrectomy was performed in combination with glaucoma surgery (tube implantation and minimally-invasive glaucoma surgery) using a digital integration of the NGENUITY, a modified GoPro camera and an endoscope. ${ }^{25} \mathrm{~A}$ small case series of strabismus surgery using the NGENUITY system has been published, reporting good feasibility and reduced need for illumination, but associated with assistant discomfort. ${ }^{26}$ Published clinical experience in cataract and anterior segment surgery using 3D heads-up display systems is summarised in Table 1.

\section{Vitreoretinal procedures}

The heads-up technique in vitreoretinal surgery was pioneered by Riemman etal. ${ }^{27}$ Eckardtetal. conducted the first published study to assess whether vitreoretinal surgery could be performed with 3D heads-up display system, using the Truevision Visualization System. ${ }^{16}$ The main 
reported advantage of heads-up technique over standard surgery was the superior ergonomics. ${ }^{16}$ Additional benefits included no increased technical difficulty compared to traditional surgery, and superior brightness of the surgical field without exposing the retina to additional light and without loss of image definition and quality. ${ }^{16}$ These findings have been corroborated in later studies using the 3D heads-up display systems (see Table 2).

The use of less light during surgery might address the potentially deleterious effect of phototoxicity related to light photon streams conducted with a traditional binocular microscope, which has always posed a risk for the surgeon and the patient due to its implications on post-operative visual acuity. ${ }^{28-30}$ Three factors may contribute to the lower requirement of endoillumination intensity of the $3 \mathrm{D}$ heads-up display vitreoretinal surgery: digital amplification and processing of the image; the high resolution of the display; and the improved depth perception. ${ }^{31}$ Furthermore, the digital enhancement of the image might allow for lesser application of vital dyes during surgery, reducing potential toxic side effects of such products. Electronic amplification of the camera's signal to increase brightness might be helpful in situations of vitreous haemorrhage, opaque media, or dark pigmented fundi. ${ }^{16}$

The NGENUITY 3D Visualization System is an FDA-regulated platform for digitally assisted vitreoretinal surgery with a 3D display, comprising four key elements: a high-dynamic range 3D digital camera that provides superb resolution, image depth, clarity and colour contrast; a high-speed graphics processing unit that processes and optimises stereoscopic images of anatomy and pathology during microsurgery; a 55-inch immersive 3D display that renders real-time images with $4 \mathrm{~K}$ organic light-emitting diode (OLED) ultra-HD technology; and passive, circularly polarised 3D glasses, with augmented reality capability. This technology reportedly provides superior stereopsis and depth perception compared with the traditional binocular surgical microscope. In addition, the NGENUITY 3D allows the simultaneous display of preoperative exams, such as optical coherence tomography (OCT) scans and fluorescein angiograms, providing great and comfortable multimodal surgeon interaction that might facilitate and shorten procedure times (Aaberg TM Jr et al. 2016, unpublished data). The feasibility of integrating intraoperative OCT with the 3D heads-up display system was analysed in a subset of patients included in the DISCOVER study, a large-scale prospective study which demonstrated that intraoperative OCT is feasible for ophthalmic surgeries and useful in surgical decision-making. ${ }^{32}$ In this pilot study, the surgical time was similar, and quality of the OCT data was improved compared with the data injection display into the microscope ocular. ${ }^{33}$

Increasing experience with the NGENUITY 3D system in vitreoretinal surgery has been published, including large patient series, ${ }^{16,24,25,31,34-36}$ as well as clinical evidence of the good surgical experience using 3D heads-up display systems for retinal detachment surgery, ${ }^{37,38}$ and for macular surgery. ${ }^{39-42}$ The 3D heads-up display system is not inferior to conventional surgery and, despite there being an 80-ms latency time compared with the standard microscope, it is not noticeable during intraocular procedures. In addition, 3D systems may reduce copiopia and asthenopia. ${ }^{19,25}$ The majority of the evidence suggests that $3 \mathrm{D}$ heads-up display provides similar surgical times, visual outcomes, and complication rates compared to conventional surgery. ${ }^{16,40,41}$ The rapid learning curve of the NGENUITY system has been confirmed in a recent prospective study assessing the learning curve in macular hole surgery. ${ }^{42}$ Published clinical experience using the 3D heads-up display systems in ophthalmic surgeries is summarised in Table 2.
Importantly, downsides of the 3D heads-up surgery have been reported, including surgeon and assistant headache, nausea and visual disturbances, which may be exacerbated after prolonged laser photocoagulation owing to the flickering green light stimulation, and the greater disturbance caused by media opacities..$^{35}$ In addition, operating theatre logistics may cause assistant discomfort owing to the positioning to visualise the monitor, and the anaesthesiologist's access to the patient may be more difficult. ${ }^{24}$

One study comparing the 3D heads-up display systems with conventional microscope for macular surgery suggested that, although total surgical times and complication rates were similar between patient groups, membrane peeling times and surgical ease were significantly different in favour of the conventional surgery group. ${ }^{41}$ However, this is conflicting with findings from other publications. ${ }^{31,40,42}$

\section{Head-mounted systems in ophthalmology}

Ivan Sutherland's early experiments in the 1960s led to the development of head-mounted display systems (HMS). ${ }^{27}$ The main applications of HMS have included military, police, firefighting, and civilian-commercial use, namely in video gaming and sports. The HMS is an active system, in which the 3D, stereoscopic image is obtained by showing high-speed consecutive images for the right and left eyes alternately. Since the first experience with HMS in ophthalmology by our group, ${ }^{43,44}$ an increasing number of devices and clinical experience have been reported. Published data on HMS for ophthalmic surgery is presented in Table 3.

\section{HMS-3000MT}

The HMS-3000MT (Sony Electronics, Tokyo, Japan) head mounted display system is a personal viewing system that provides a 3D colour video display of images from 3D surgical camera systems. It consists of the HMI-3000MT image processor unit plus the HMM-3000MT head mounted display, which provides a stereoscopic visualisation of the end-footage from an imaging system, and a 3D colour video display of images from the 3D, full-HD surgical camera systems, MCC-3000MT. This system has the option to connect a second head mounted monitor, giving other theatre staff a simultaneous $3 \mathrm{D}$ view. This device is compliant and certified for IEC 60601-1 and product safety standards in the USA, Canada and Europe. This information is available at the company's official website.45 Depth perception inside the HMS device requires different images for the left and right eyes. It presents two simultaneous images, one for each eye, avoiding the ghosting image effect caused by cross-talk. The system of dual video input using two independent OLED panels offers a complete separate video signal to each eye, which provides the maximum resolution for each image, and maximum frame rate for each eye. The HMS provides high-resolution (1,280 x 720) stereoscopic images with precise reproduction of colours and blacks.

The use of this innovative HMS technology in ophthalmology was first reported by Dutra-Medeiros et al.43,44 Several ophthalmic surgeries were performed in 2016 using the Haag-Streit Surgical microscope HS Hi-R NEO 900 (Haag-Streit Surgical GmbH, Wedel, Germany) connected to the Sony Head-Mounted System HMS-3000 MT device, which included pars plana vitrectomy, both as a sole procedure and combined with phacoemulsification and IOL implantation. Other vitreoretinal techniques were performed, including extraction of a posteriorly dislocated IOL, epiretinal membrane peeling, internal limiting membrane peeling, endolaser photocoagulation, and tamponade with silicone oil and sulphur hexafluoride gas.

Published clinical experience using the Sony HMS-3000MT helmet in ophthalmic surgeries, ${ }^{15,43}$ suggests the device is well-fitted and not 
Table 2: Clinical experience with 3D heads-up viewing systems in vitreoretinal surgery

\begin{tabular}{|c|c|c|c|c|c|}
\hline Authors & Technology & Study & Surgery & Outcomes & Comments \\
\hline $\begin{array}{l}\text { Riemman } \\
2011^{27}\end{array}$ & $\begin{array}{l}\text { TrueVision }^{\circledast} \text { 3D } \\
\text { System } \\
\text { (TrueVision Systems } \\
\text { Inc., CA, USA) }\end{array}$ & $\begin{array}{l}\text { Pilot vitrectomy case } \\
\text { series using 3D HUD } \\
\text { systems }\end{array}$ & $\begin{array}{l}\text { 25-gauge PPV } \\
\text { + additional VR } \\
\text { techniques } \\
\text { +/- combined } \\
\text { cataract surgery }\end{array}$ & $\begin{array}{l}\text { Good surgical outcomes, no } \\
\text { complications. Great surgeon } \\
\text { comfort, good visualisation }\end{array}$ & $\begin{array}{l}\text { Pilot study of VR surgery, } \\
\text { no need to look through the } \\
\text { microscope oculars }\end{array}$ \\
\hline $\begin{array}{l}\text { Eckardt et al. } \\
2016^{16}\end{array}$ & $\begin{array}{l}\text { TrueVision 3D } \\
\text { System }\end{array}$ & SOM versus 3D HUS & $\begin{array}{l}\text { PPV + additional } \\
\text { VR techniques } \\
\text { +/- combined } \\
\text { cataract surgery }\end{array}$ & $\begin{array}{l}\text { Superior ergonomics of the heads-up } \\
\text { technology. Similar speed and ease } \\
\text { of manipulation of instruments. } \\
\text { HUS allowed use of reduced } \\
\text { endoillumination levels }\end{array}$ & $\begin{array}{l}\text { Similar sharpness of image. } \\
\text { Resolution of the eyepieces was } \\
\text { higher than the HUS, whereas depth } \\
\text { of field was about equal. Reduced } \\
\text { endoillumination level requirements }\end{array}$ \\
\hline $\begin{array}{l}\text { Skinner et al. } \\
2018^{37}\end{array}$ & $\begin{array}{l}\text { NGENUITY }{ }^{\circledR} \text { 3D } \\
\text { Visualization System } \\
\text { (Alcon, TX, USA) }\end{array}$ & Case report & $\begin{array}{l}\text { 25-gauge PPV } \\
\text { + additional VR } \\
\text { techniques for } \\
\text { retinal detachment }\end{array}$ & $\begin{array}{l}\text { Good anatomic and visual outcomes } \\
\text { postoperatively. Superb surgeon } \\
\text { comfort, great surgical time }\end{array}$ & $\begin{array}{l}\text { Allowed VR surgery in a severely } \\
\text { kyphotic patient with good control of } \\
\text { patient pain throughout the surgery }\end{array}$ \\
\hline $\begin{array}{l}\text { Adam et al. } \\
2017^{30}\end{array}$ & $\begin{array}{l}\text { TrueVision 3D } \\
\text { System }\end{array}$ & $\begin{array}{l}\text { Prospective, single-centre } \\
\text { case series to assess } \\
\text { endoillumination levels } \\
\text { and display luminous } \\
\text { emittance }\end{array}$ & $\begin{array}{l}\text { PPV + additional } \\
\text { VR techniques } \\
\text { +/- combined } \\
\text { cataract surgery }\end{array}$ & $\begin{array}{l}\text { No surgical complications. Surgeons } \\
\text { felt comfortable operating at } \\
\text { endoillumination level of } 10 \% \\
\text { with display emittance of } 14.3 \pm \\
9.5 \text { lux, and safely down to } 3 \% \\
\text { endoilluminance level }\end{array}$ & $\begin{array}{l}\text { A direct positive correlation was } \\
\text { found between endoillumination } \\
\text { levels and luminous emittance from } \\
\text { the 3D screen. 3D HUD system } \\
\text { platforms reduce intraoperative } \\
\text { endoillumination level requirements }\end{array}$ \\
\hline $\begin{array}{l}\text { Kunikata } \\
\text { et al. } 2016^{39}\end{array}$ & $\begin{array}{l}\text { MKC-700HD and } \\
\text { CFA-3DL1 } \\
\text { (Ikegami, Tokyo, } \\
\text { Japan) }\end{array}$ & $\begin{array}{l}\text { Retrospective study of } \\
\text { vitrectomy to assess } \\
\text { endoillumination levels } \\
\text { for macular surgery }\end{array}$ & $\begin{array}{l}\text { 27-gauge PPV } \\
\text { for macular } \\
\text { surgery using 1\% } \\
\text { endoillumination }\end{array}$ & $\begin{array}{l}\text { The 3D HUD system allowed easier } \\
\text { visualisation of the macula compared } \\
\text { with conventional microscope. Good } \\
\text { patient outcomes and safety profile }\end{array}$ & $\begin{array}{l}\text { 3D screen. 3D heads-up display } \\
\text { system platforms reduce } \\
\text { intraoperative endoillumination level } \\
\text { requirements in macular surgery }\end{array}$ \\
\hline $\begin{array}{l}\text { Coppola } \\
\text { et al. } 2017^{38}\end{array}$ & $\begin{array}{l}\text { NGENUITY 3D } \\
\text { Visualization System }\end{array}$ & $\begin{array}{l}\text { SOM versus 3D HUD } \\
\text { for retinal detachment } \\
\text { surgery }\end{array}$ & $\begin{array}{l}\text { 25-gauge PPV } \\
\text { + additional VR } \\
\text { techniques } \\
\text { +/- combined } \\
\text { cataract surgery }\end{array}$ & $\begin{array}{l}\text { Mean endoillumination power } \\
\text { was significantly lower in the } \\
\text { 3D HUD surgeries compared } \\
\text { with conventional microscope; } \\
\text { triamcinolone staining of vitreous } \\
\text { was not necessary with 3D HUD }\end{array}$ & $\begin{array}{l}\text { 3D HUD showed good surgical } \\
\text { efficacy and safety, and reduced } \\
\text { requirement of illumination power } \\
\text { in retinal detachment surgery }\end{array}$ \\
\hline $\begin{array}{l}\text { Romano } \\
\text { et al. } 2018^{35}\end{array}$ & $\begin{array}{l}\text { Panoramic RUV800 } \\
\text { Viewing System } \\
\text { for Retinal Surgery } \\
\text { (Leica Microsystems, } \\
\text { Wetzlar, Germany) }\end{array}$ & $\begin{array}{l}\text { Pilot prospective study of } \\
\text { vitrectomy: SOM versus } \\
\text { 3D HUD }\end{array}$ & $\begin{array}{l}\text { 25-gauge PPV } \\
\text { + additional VR } \\
\text { techniques } \\
\text { +/- combined } \\
\text { cataract surgery }\end{array}$ & $\begin{array}{l}\text { Slightly longer mean surgery times } \\
\text { with 3D HUD. Superior surgeon } \\
\text { comfort and depth perception with } \\
\text { 3D HUD system. No increased risk } \\
\text { of complications }\end{array}$ & $\begin{array}{l}\text { 3D HUD systems showed superior } \\
\text { potential for VR surgical training } \\
\text { compared with SOM }\end{array}$ \\
\hline $\begin{array}{l}\text { Kita et al. } \\
2018^{36}\end{array}$ & $\begin{array}{l}\text { NGENUITY 3D } \\
\text { Visualization System }\end{array}$ & $\begin{array}{l}\text { Retrospective study of } \\
\text { vitrectomy using a hybrid } \\
\text { wide-angle viewing } \\
\text { endoscopic vitrectomy } \\
\text { procedure that uses a 3D } \\
\text { HUD system }\end{array}$ & $\begin{array}{l}\text { 25-gauge PPV } \\
\text { + additional VR } \\
\text { techniques } \\
\text { +/- combined } \\
\text { cataract surgery }\end{array}$ & $\begin{array}{l}\text { Good surgical outcomes, without } \\
\text { surgical complications. Enhanced } \\
\text { magnification of image and reduced } \\
\text { illumination levels }\end{array}$ & $\begin{array}{l}\text { 3D HUD allowed performing hybrid } \\
\text { vitrectomy even in the most } \\
\text { challenging cases }\end{array}$ \\
\hline $\begin{array}{l}\text { Kumar et al. } \\
2018^{40}\end{array}$ & Unspecified device & $\begin{array}{l}\text { Prospective, randomised } \\
\text { comparative study of } \\
\text { 3D HUD versus SOM in } \\
\text { macular hole surgery }\end{array}$ & $\begin{array}{l}\text { Unspecified } \\
\text { vitrectomy gauge }\end{array}$ & $\begin{array}{l}\text { Similar visual outcomes, total } \\
\text { surgical time, ILM peeling time, and } \\
\text { macular hole closure rates }\end{array}$ & $\begin{array}{l}\text { 3D HUD systems required } \\
\text { significantly lower illumination } \\
\text { intensity of the microscope and } \\
\text { endoillumination }\end{array}$ \\
\hline $\begin{array}{l}\text { Talcott et al. } \\
2019^{41}\end{array}$ & $\begin{array}{l}\text { NGENUITY 3D } \\
\text { Visualization System }\end{array}$ & $\begin{array}{l}\text { Prospective, single-centre, } \\
\text { randomised study to } \\
\text { compare 3D HUD to SOM } \\
\text { for macular pathology }\end{array}$ & $\begin{array}{l}\text { PPV + membrane } \\
\text { peeling }\end{array}$ & $\begin{array}{l}\text { Similar operative time and visual } \\
\text { outcomes; lower endoillumination } \\
\text { levels using 3D HUD, but macular peel } \\
\text { time significantly longer using 3D HUD }\end{array}$ & $\begin{array}{l}\text { 3D HUD expected to require less } \\
\text { intravitreal triamcinolone for } \\
\text { hyaloid staining, but use was similar } \\
\text { between groups }\end{array}$ \\
\hline $\begin{array}{l}\text { Zhang et al. } \\
2019^{31}\end{array}$ & $\begin{array}{l}\text { NGENUITY 3D } \\
\text { Visualization System }\end{array}$ & $\begin{array}{l}\text { Non-randomised } \\
\text { case-control study to } \\
\text { evaluate light levels, } \\
\text { surgical times and } \\
\text { surgeon preferences }\end{array}$ & $\begin{array}{l}\text { 25-gauge PPV +/- VR } \\
\text { techniques }\end{array}$ & $\begin{array}{l}\text { Surgeons expressed overwhelming } \\
\text { preference with the 3D HUS; lower } \\
\text { light levels using 3D HUS }\end{array}$ & $\begin{array}{l}\text { Surgical difficulties perceived using } \\
\text { 3D HUS included patient's head } \\
\text { movement during indentation; } \\
\text { media opacities, headache and } \\
\text { nausea mainly after prolonged laser } \\
\text { photocoagulation }\end{array}$ \\
\hline $\begin{array}{l}\text { Rizzo et al. } \\
2018^{24}\end{array}$ & $\begin{array}{l}\text { NGENUITY 3D } \\
\text { Visualization System }\end{array}$ & $\begin{array}{l}\text { Assessment of surgical } \\
\text { team satisfaction using } \\
\text { the 3D HUD system }\end{array}$ & $\begin{array}{l}200 \text { consecutive } \\
\text { cases, both anterior } \\
\text { and posterior } \\
\text { segment surgeries }\end{array}$ & $\begin{array}{l}\text { High surgeon and nurse satisfaction } \\
\text { scores, but assistant surgeon needed } \\
\text { to adopt an uncomfortable position, } \\
\text { and anaesthesiologist reported } \\
\text { logistic problems }\end{array}$ & $\begin{array}{l}\text { Also performed corneal } \\
\text { transplantation, squint surgery, and } \\
\text { Argus-II retinal implant surgery }\end{array}$ \\
\hline
\end{tabular}


Table 2: Cont.

\begin{tabular}{|l|l|l|l|l|l|}
\hline $\begin{array}{l}\text { Palácios } \\
\text { et al. 201925 }\end{array}$ & $\begin{array}{l}\text { NGENUITY 3D } \\
\text { Visualization System }\end{array}$ & $\begin{array}{l}\text { Prospective, comparative } \\
\text { study to compare 3D } \\
\text { HUD verus SOM surgery }\end{array}$ & $\begin{array}{l}\text { PPV +/-additional } \\
\text { procedures, including } \\
\text { glaucoma surgery } \\
\text { and cataract surgery }\end{array}$ & $\begin{array}{l}\text { After 1 year of clinical experience, } \\
\text { surgeons overall preferred 3D } \\
\text { surgery over conventional surgery, } \\
\text { particularly for ILM and epiretinal } \\
\text { membrane peeling }\end{array}$ & $\begin{array}{l}\text { Glaucoma surgery (Ahmed } \\
\text { Glaucoma Valve, iStent } \\
\text { implantation) } \\
\text { using a digital integration of the } \\
\text { NGENUITY, a modified GoPro } \\
\text { camera and an endoscope }\end{array}$ \\
\hline $\begin{array}{l}\text { Zhang et al. } \\
\text { 201934 }\end{array}$ & $\begin{array}{l}\text { NGENUITY 3D } \\
\text { Visualization System }\end{array}$ & $\begin{array}{l}\text { Retrospective case series } \\
\text { comparing 3D HUD } \\
\text { versus SOM }\end{array}$ & $\begin{array}{l}\text { 23-gauge PPV } \\
+/ \text { - additional VR } \\
\text { techniques }\end{array}$ & $\begin{array}{l}\text { Visual outcomes, surgical times and } \\
\text { complication rates were comparable } \\
\text { between 3D and traditional } \\
\text { microscopy }\end{array}$ & - \\
\hline $\begin{array}{l}\text { Palácios } \\
\text { et al. 201942 }\end{array}$ & $\begin{array}{l}\text { NGENUITY 3D } \\
\text { Visualization System }\end{array}$ & $\begin{array}{l}\text { Determination of the } \\
\text { learning curve of 3D HUS } \\
\text { surgery for macular hole } \\
\text { surgery }\end{array}$ & $\begin{array}{l}\text { Pars plana vitrectomy } \\
\text { with ILM peeling }\end{array}$ & $\begin{array}{l}\text { Short learning curve, similar surgical } \\
\text { and ILM peeling times between } \\
\text { 3D surgery and conventional } \\
\text { microscope }\end{array}$ & $\begin{array}{l}\text { Surgeons considered traditional } \\
\text { microscopy more ergonomic }\end{array}$ \\
\hline
\end{tabular}

$3 D=$ three-dimensional; HD = high definition; HUD = heads-up display; HUS = heads-up system; ILM = inner limiting membrane; PPV = pars plana vitrectomy; SOM = standard operating microscope; $V R=$ vitreoretinal

Table 3: Head-mounted systems in ophthalmic surgery

\begin{tabular}{|c|c|c|c|c|c|}
\hline Authors & Technology & Study & Surgery & Outcomes & Comments \\
\hline $\begin{array}{l}\text { Dutra-Medeiros } \\
\text { et al. } 2017^{43}\end{array}$ & $\begin{array}{l}\text { HMS-3000MT Head } \\
\text { Mounted Display } \\
\text { System (Sony } \\
\text { Electronics, Tokyo, } \\
\text { Japan) }\end{array}$ & $\begin{array}{l}\text { Pilot vitrectomy } \\
\text { case series using } \\
\text { 3D HMS systems }\end{array}$ & $\begin{array}{l}\text { 23-gauge PPV + } \\
\text { additional VR techniques } \\
\text { +/- combined cataract } \\
\text { surgery }\end{array}$ & $\begin{array}{l}\text { Short learning curve, } \\
\text { good image quality, great } \\
\text { depth perception, superior } \\
\text { ergonomics }\end{array}$ & $\begin{array}{l}\text { The HMS showed very high potential } \\
\text { for VR surgical training compared with } \\
\text { conventional microscope. We believe } \\
\text { depth perception with HMS to be slightly } \\
\text { superior to 3D HUD systems }\end{array}$ \\
\hline $\begin{array}{l}\text { Martínez-Toldos } \\
\text { et al. } 2017^{15}\end{array}$ & $\begin{array}{l}\text { HMS-3000MT Head } \\
\text { Mounted Display } \\
\text { System }\end{array}$ & Case series & $\begin{array}{l}\text { 23-gauge PPV + } \\
\text { additional VR techniques } \\
\text { +/- combined cataract } \\
\text { surgery }\end{array}$ & $\begin{array}{l}\text { Short adaptation time, short } \\
\text { learning curve, good image } \\
\text { quality, great depth perception, } \\
\text { superior ergonomics }\end{array}$ & $\begin{array}{l}\text { The HMS showed good ergonomics and } \\
\text { very high potential for VR surgical training } \\
\text { compared with conventional microscope }\end{array}$ \\
\hline $\begin{array}{l}\text { Korot et al. } \\
2018^{46}\end{array}$ & $\begin{array}{l}\text { Avegant Glyph } \\
\text { retinal projection } \\
\text { display system }\end{array}$ & $\begin{array}{l}\text { Pilot study using } \\
\text { VitRet eye models }\end{array}$ & $\begin{array}{l}\text { Assessment of the } \\
\text { safety and confidence } \\
\text { of the device }\end{array}$ & $\begin{array}{l}\text { Safe imaging modality with } \\
\text { high depth of field }\end{array}$ & $\begin{array}{l}\text { Surgeons displayed high levels of } \\
\text { confidence to safely perform procedures. } \\
\text { Glyph may be useful for scleral depression }\end{array}$ \\
\hline $\begin{array}{l}\text { Lowenstein et al. } \\
2019^{48}\end{array}$ & $\begin{array}{l}\text { Clarity }^{\circledR} \text { Platform } \\
\text { (Beyeonics } \\
\text { Surgical, Haifa, } \\
\text { Israel) }\end{array}$ & $\begin{array}{l}\text { Pilot vitrectomy } \\
\text { case series using } \\
\text { Clarity }\end{array}$ & $\begin{array}{l}\text { PPV + additional VR } \\
\text { techniques }\end{array}$ & $\begin{array}{l}\text { Good image quality, superior } \\
\text { maximum magnification } \\
\text { compared with standard } \\
\text { operating microscope, } \\
\text { half-light levels }\end{array}$ & $\begin{array}{l}\text { Yet difficult to integrate iOCT technology; } \\
\text { the helmet is not wireless }\end{array}$ \\
\hline
\end{tabular}

$3 D=$ three-dimensional; HMS = head-mounted system; HUD = heads-up display; iOCT = intraoperative optical coherence tomography; PPV = pars plana vitrectomy; $V R=$ vitreoretinal

uncomfortable, with superior ergonomics; great image quality, depth perception and spatial orientation; $45^{\circ}$ diagonal field of view; and short adaptation time and learning curve.

\section{Avegant Glyph head-mounted virtual retinal projection display}

The Avegant Glyph retinal projection system (Avegant Corp., Belmont, CA, USA) employs a virtual retinal display technology, in which the image is directly projected onto the user's retina. ${ }^{46}$ It uses a three-colour LED to project a 1,280 x 720 image onto a micromirror array, which is reflected and focused through its optics to project directly onto the user's retina. Images are projected into each eye independently to render depth perception and stereopsis. It has a $40^{\circ}$ diagonal field of view, and has an integrated head tracking gyroscope array. The device is connected to a 3D, HD camera attached to the surgical microscope.

The pilot experience using vitrectomy eye models suggests vitreoretinal surgery is feasible using this device, providing a high depth of field. ${ }^{46}$ It may have a superior ergonomics profile compared with 3D heads-up surgery. In addition, it appears to provide an enhanced view for procedures requiring simultaneous intra- and extraocular visualisation, such as scleral depression. ${ }^{46}$

\section{Clarity head-mounted display system}

The Clarity ${ }^{\top M}$ (Beyeonics Surgical, Haifa, Israel) platform provides an augmented-reality view of the surgery. The platform includes dual 3D, ultra HD-resolution cameras suspended on a remote arm and a transparent head-wearable display, and a processing core which allows for integration from multiple digital sources in real-time with zero latency. Using head motions, the surgeon can shift between different visual screens projected onto his retina, allowing control of focus, transparency, and light levels. This information is available on the Beyeonics company's official website. ${ }^{47}$

A pilot study using the Clarity platform for vitreoretinal surgeries was conducted on 40 eyes. ${ }^{48}$ The image quality appears to be comparable to that of standard microscope, and the HMS provided superior maximum magnification, with half the light level requirements. Surgeon experience was positive, without reported fatigue, comfortable posture, and intuitive head motions. 
The main practical difference between the Clarity, the HMS-3000MT and the Avegant Glyph is that the Clarity helmet is not yet wireless, which poses a limitation in terms of logistics. ${ }^{48}$ The Avegant Glyph platform may provide lesser visual obstruction of the real world compared with the HMS-3000MT system. ${ }^{46}$ To date, no clinical studies have been conducted to compare the surgical results using different head-mounted display devices.

In terms of technical-surgical applicability, the HMS allows the user to suppress the physical distance inherent to the heads-up display with the consequent loss of image definition and stereopsis, improving and optimising the surgeon's technical capacity.

\section{Conclusion}

Three-dimensional display systems are increasingly demonstrating good results in ophthalmology, both for anterior segment and vitreoretinal surgeons. Heads-up surgery using 3D display screens has been gaining acceptance, with more reports and experience using this technology. The use of HMS is also being increasingly reported in ophthalmology. HMS technology in vitreoretinal surgery has a short learning curve, and provides excellent visual experience with greater ergonomics compared with traditional surgery. In addition, both headsup and HMS 3D technology allow for less light delivery to the retina during vitreoretinal surgery, potentially allowing for less phototoxicity during vitreoretinal procedures. ${ }^{16}$

However, some limitations of current 3D visualisation systems are being investigated and are worth overcoming, most notably assistant discomfort and operating theatre logistics, visual disturbance by media opacities, and surgeon headache and nausea after prolonged laser photocoagulation. Some HMS devices will require becoming wireless before being more widely adopted. Finally, an early and insufficient surgical learning curve may lead to technical errors in the intraoperative period, which may pose significant risk to the final result of the surgery. More experience with this technology in ophthalmology is needed and strongly encouraged.

Both 3D heads-up display and HMS technologies have excellent potential for live surgery teaching and training in the short term. From the teaching standpoint, the 3D systems have remarkable advantages over standard binocular microscope surgery. 3D systems allow every element of the surgical team, as well as larger audiences, to fully appreciate the surgeon's view with great depth perception and clarity; they allow high-quality recordings of surgery to further analyse and discuss; and improved assistant visualisation allows for surgeons to better assist and teach trainees by assessing finer surgical manoeuvres that are not as readily observed in the main microscope ${ }^{49}[$
1. Mendez BM, Chiodo MV, Vandevender D, Patel PA. Heads-up 3D microscopy: an ergonomic and educational approach to microsurgery. Plast Reconstr Surg Glob Open. 2016;4:e717.

2. Dhimitri KC, MCGwin G Jr, McNeal SF, et al. Symptoms of musculoskeletal disorders in ophthalmologists. Am 」 Ophthalmol. 2005:139:179-81.

3. Hyer JN, Lee RM, Chowdhury HR, et al. National survey of back \& neck pain amongst consultant ophthalmologists in the United Kingdom. Int Ophthalmol. 2015;35:769-75.

4. Honavar SG. Head up, heels down, posture perfect: ergonomics for an ophthalmologist. Indian J Ophthalmol. 2016;65:647-50.

5. Shaw C, Bourkiza R, Wickham L, et al. Mechanical exposure of ophthalmic surgeons: a quantitative ergonomic evaluation of indirect ophthalmoscopy and slit-lamp biomicroscopy. Can J Ophthalmol. 2017;52:302-7.

6. Toyooka T, Otani N, Wada K, et al. Head-up display may facilitate safe keyhole surgery for cerebral aneurysm clipping. J Neurosurg. 2018;129:883-9.

7. Mascitelli JR, Schlachter L, Chartrain AG, et al. Navigation-linked heads-up display in intracranial surgery: early experience. Oper Neurosurg (Hagerstown). 2018;15:184-93.

8. Bickerton R, Nassimizadeh AK, Ahmed S. Three-dimensional endoscopy: the future of nasoendoscopic training. Laryngoscope. 2019;129:1280-5

9. Rose AS, Kim H, Fuchs H, Frahm JM. Development of augmented-reality applications in otolaryngology-head and neck surgery. Laryngoscope. 2019; doi: 10.1002/lary.28098 neck surgery. Laryngosc

10. Bosc R, Fitoussi A, Hersant B, Dao TH, Meningaud JP. Intraoperative augmented reality with heads-up displays in maxillofacial surgery: a systematic review of the literature and a classification of relevant technologies. Int I Oral Maxillofac Surg. 2019;48:132-9.

11. Dirie NI, Wang $\mathrm{Q}$, Wang $\mathrm{S}$. Two-dimensional versus threedimensional laparoscopic systems in urology: a systematic review and meta-analysis. J Endourol. 2018;32:781-90.

12. Tao K, Liu X, Deng M, et al. Three-dimensional against 2-dimensional laparoscopic colectomy for right-sided colon cancer surg Laparosc Endosc Percutan Tech. 2016;26:324-7.

13. Komaei I, Navarra G, Currò G. Three-dimensional versus two-dimensional laparoscopic cholecystectomy: a systematic review I Laparoendosc Adv Surg Tech A. 2017:27:790-4.

14. Fotouhi J. Fuerst B, Lee SC, et al. Interventional 3D augmented reality for orthopedic and trauma surgery. Presented at: 16th Annual Meeting of the International Society for Computer Assisted Orthopedic Surgery, Osaka, Japan, 8-11 June, 2016.

15. Martínez-Toldos JJ, Fernández-Martínez C, Navarro-Navarro A Experience using a 3D head-mounted display system in ophthalmic surgery. Retina. 2017;37:1419-21.

16. Eckardt C, Paulo EB. Heads-up surgery for vitreoretinal procedures: an experimental and clinical study. Retina. 2016;36:137-47

7. Weinstock RJ, Desai N. Heads-up cataract surgery with the TrueVision 3D display system. In: Garg A, Alio IL, (eds). Surgical
Techniques in Ophthalmology—Cataract Surgery. New Dehli, India: Jaypee Medical Publishers. 2010;124-7.

18. Weinstock RJ. Operate with your head up. Cataract Refract Surg Today. 2011;66:8.

19. Weinstock RJ, Diakonis VF, Schwartz AJ, Weinstock AJ. Heads-up cataract surgery: complication rates, surgical duration, and comparison with traditional microscopes. J Refract Surg. 2019;35:318-22

20. TrueVision 3D Surgical. Refractive Cataract Toolset ${ }^{\oplus}$. Intelligent 3D Guidance for Astigmatic Correction and Lens Positioning. Available at: www.yumpu.com/en/document/read/36919369/ download-refractive-cataract-toolset-brochure-pdf-truevisiondownload-refractive-catar

21. Leica Microsystems. IOL Guidance Systems. IOLcompass \& $3 D$ TrueGuide. Available at: https://downloads.leica-microsystems com/IOLCompass/Brochures/IOL\%20guidance\%20brochure_. en.pdf (accessed 9 August 2019).

22. Mohamed YH, Uematsu M, Inoue D, Kitaoka T. First experience of nDSAEK with heads-up surgery: a case report. Medicine (Baltimore). 2017;96:e6906.

23. Galvis V, Berrospi RD, Arias JD, et al. Heads up Descemet membrane endothelial keratoplasty performed using a 3D visualization system. J Surg Case Rep. 2017; rjx231.

24. Rizzo S, Abbruzzese G, Savastano A, et al. 3D surgical viewing system in ophthalmology: perceptions of the surgical team. Retina. 2018;38:857-61.

25. Palácios RM, de Carvalho ACM, Maia M, et al. An experimental and clinical study on the initial experiences of Brazilian vitreoretinal surgeons with heads-up surgery. Graefes Arch Clin Exp Ophthalmol. 2019;257:473-83.

26. Hamasaki I, Shibata K, Shimizu T, et al. Lights-out surgery for strabismus using a heads-up 3D vision system. Acta Med Okayama. 2019;73:229-33.

27. Riemann $C D$. Machine vision and vitrectomy: three-dimensiona high definition (3DHD) video for surgical visualization in vitreoretinal surgery. Proceedings of the SPIE Volume 7863. Stereoscopic Displays and Applications XXII. 25 January 2011 San Francisco, CA, USA

28. Höh AE, Ach T, Amberger R, Dithmar S. Lichtexposition bei vitreoretinaler Chirurgie. Der Ophthalmologe. 2008;105:898-904

29. Youssef PN, Sheibani N, Albert DM. Retinal light toxicity. Eye (Lond). 2011:25:1-14

30. Adam MK, Thornton $S$, Regillo $C D$, et al. Minimal endoillumination levels and display luminous emittance during three-dimensional heads-up vitreoretinal surgery. Retina. 2017;37:1746-9.

31. Zhang Z, Wang L, Wei Y, et al. The preliminary experiences with three-dimensional heads-up display viewing system for vitreoretinal surgery under various status. Curr Eye Res. 2019;44:102-9.

32. Ehlers JP, Modi YS, Pecen PE, et al. The DISCOVER study 3-year results: feasibility and usefulness of microscope-integrated intraoperative OCT during ophthalmic surgery. Ophthalmology. 2018;125:1014-27.

33. Ehlers JP, Uchida A, Srivastava SK. The integrative surgica theater: combining intraoperative optical coherence tomography and $3 \mathrm{D}$ digital visualization for vitreoretinal surgery in the DISCOVER study. Retina. 2018;38(Suppl 1):S88-96

34. Zhang T, Tang W, Xu G. Comparative analysis of threedimensional heads-up vitrectomy and traditional microscopic vitrectomy for vitreoretinal diseases. Curr Eye Res. 2019; doi: 10.1080/02713683.2019.1612443 [Epub ahead of print].

35. Romano MR, Cennamo G, Comune C, et al. Evaluation of 3D heads-up vitrectomy: outcomes of psychometric skills testing and surgeon satisfaction. Eye (Lond). 2018;32:1093-8.

36. Kita M, Mori Y, Hama S. Hybrid wide-angle viewing-endoscopic vitrectomy using a 3D visualization system. Clin Ophthalmol. 2018:12:313-7.

37. Skinner CC, Riemann CD. "Heads up" digitally assisted surgica viewing for retinal detachment repair in a patient with severe kyphosis. Retina Cases Brief Rep. 2018;12:257-9.

38. Coppola M, La Spina C, Rabiolo A, et al. Heads-up 3D vision system for retinal detachment surgery. Int I Retin Vitr. 2017;3:46

39. Kunikata H, Abe T, Nakazawa T. Heads-up macular surgery with a 27-gauge microincision vitrectomy system and minimal illumination. Case Rep Ophthalmol. 2016;7:265-9.

40. Kumar A, Hasan N, Kakkar P, et al. Comparison of clinical outcomes between "heads-up" 3D viewing system and conventional microscope in macular hole surgeries: a pilot study. Indian J Ophthalmol. 2018;66:1816-9.

41. Talcott KE, Adam MK, Sioufi K, et al. Comparison of threedimensional heads-up display surgical platform to standard
operating microscope for macular surgery. Ophthalmol Retina. operating microsco

42. Palácios RM, Maia A, Farah ME, Maia M. Learning curve of three-dimensional heads-up vitreoretinal surgery for treating macular holes: a prospective study. Int Ophthalmol. 2019; doi: 10.1007/s10792-019-01075-y [Epub ahead of print].

43. Dutra-Medeiros M, Nascimento J, Henriques J, et al. Threedimensional head-mounted display system for ophthalmic surgical procedures. Retina. 2017;37:1411-4

44. Dutra-Medeiros M, Moura-Coelho N, Nascimento J, et al. Correspondence - Three-dimensional (3D) head-mounted display systems in ophthalmic surgery - first reports. Retina. 2017;37:e118.

45. Sony. HMS-3000MT 3D Head Mounted Display System. Available at: https://pro.sony/en_GB/products/surgical-monitors/hms3000mt (accessed 9 August 2019).

46. Korot E, Thanos A, Todorich B, et al. Use of the Avegant Glyph head-mounted virtual retinal projection display to perform vitreoretinal surgery. J Vitreoretin Dis. 2018;2:22-5.

47. Beyeonic ${ }^{\mathrm{T} M}$. Clarity TM $^{\mathrm{T}}$ Platform. Available at: www. beyeonics. $\mathrm{com} /$ (accessed 9 August 2019).

48. Lowenstein A, Schneider R, Barak A. First look: a head-mounted OR display. 2019. Available at: www. reviewofophthalmology.com/article/first-look-aheadmounted-or-display (accessed 25 July 2019).

49. Eckardt C, Ahdab K, Eckert T. Use of mobile phones during heads-up surgery-a new way of teaching cataract and vitreoretinal surgery. Retina. 2019; doi: 10.1097/ IAE.00000000000002493 [Epub ahead of print]. 